\title{
DIAKONI W AUGUSTYNOWEJ KONCEPCJI KOŚCIOŁA
}

1. Można mówić o trzech przyczynach, które miały wpływ na wypracowanie Augustynowej teologii Kościoła: duszpasterstwo, spór $z$ donatystami $i$ nauka o łasce ${ }^{1}$. Kaźda $z$ nich decyduje o swoistym ujęciu rzeczywistości Kościoła, ale teź każdy z tych współelementów w nim wystegpuje. Jest to zatem jedynie podział teoretyczny.

a/ Tak więc z troski o przybliżenie wiernym obrazu Kościoła wynika przedstawienie go jako ciała, którego głowa jest Chrystus. Zwiazzels ów jest tak ścisły, że jest to jedna osoba: " unus homo, unus vir, una persona, Christus Integer lub totus ", a przy wyjaśnianiu tego misterium powoływał sie Augustyn na Dz 9 , 4 /"Szawle, Szawle, dlaczego mnie prześladujesz?"/ i Ef 5, 31 $/ z$ odniesieniem do $\operatorname{Rdz} 2,24$ : "będą dwoje jedny ciałem"/2.

b/ Spór z donatystani postawił problein teologii sakramentów, a konkretnie podıniotu sakranentalnego działania. Działającym nie jest Kościół, jak chcieli donatyści, ale Chrystus: "Piotr chrzci - san Chrystus jest tyın, który chrzci /.../ Judasz chrzci 1 chrzci Chrystus" ${ }^{3}$. Oznacza to, ze Kościół nio sprawuje władzy /potestas/, lecz spełnia posiuge /ministerium/ sakramentalną.

c/Kościół w obrazie państwa Bożego, nie instytucj1 czy społeczności, ale rzeczywistości mistycznej, nie na sposób tylko

1 Por. Y. Congar, Die Lehre von der Kirche. Von Augustinus bis zum Abendlandischen Schisma/Handbuch der Dogmengeschichte, Bd. III, Fasz. $3 \mathrm{c} /$, Freiburg 1971, 1-10.

2 Odniesienia u Congara, taù̇e, 2, przyp. 2-3.

3 In Joannis Evargelium 6, 7, PL 35, 1428. Na tę nauke powołuje się Sobór iratykański II w Konstytucji o liturgii "Sacrosanctum Concilium" 7. W Kościele many do czynienia z droma stopniam1, które sugustyn zazwyczaj określa jako "communio sacramentorum" i "societas sanctorum", por. Congar, dz.cyt., 5. 
czystej idei, lecz konkretnej rzeczywistości, określonej jako urzeczywistnienie duchowego ideału. Do opisania tej rzeczywistości używa Augustyn tak nazwy "Kościół", Jak 1 "państro Boże", ale nie jest ona wymieszana. "Civitas Dei" zawiera w sobie Kościół, o ile ten jest "congregatio sanctorum "4.

2. Dokonujac refleksji nad tyini trzema ujęciami rzeczywistości Kościoła, wzajemnie si̊ przenikajacyini, pytałem jednocześnie o zasadę porząukującą $i$ podporządkowującą zarazem Augustynowa eklezjologię. Wydaje się, że jego teologia Kościoła posiada znamiona diakonijne /diakońskie/. Mieliśmy już okazjq wskazać na ten wyaiar, mówiąc o podniocie sakranentalnego działania: Kościół nie sprawuje władzy/potestas/, lecz spełnia posługe /ministerium/sakramentalniz. W jednej ze swych mów strierdza: "jestem tylko sługa, a nie gospodarzem".

Vi swych dysputach $z$ heretykani $i$ schizmatykami św. Augustyn przekonany o wielkości Kościola/magna, catholica/, podkreśla jednocześnie prawdę, że jest to "humilis ecclesia" 5 . Z kolei ani pokora, o której mowa, ani caritas, będąca jej drugą stroną, nie stanowia tylko o doskonałości etycznej człowieka, lecz należy je traktować przede wszystkim także jako cnoty eklezjologiczne ${ }^{6}$. Diakonijny wyıiar Kościoła objawia się także poprzez jałmużnę $i$ post ${ }^{7}$, troşlie o uchodźców i okazywanie gościnno-

4 Congar, dz.cyt., 7: "Dieses sehr starke Bewusstsein von e1ner Kirche, die im Exil unterwegs ist, hindert Augustinus nicht, daran festzuhalten, dass diese irirche scilon das "regnum Dei" ist und dass ihre gegenwartige Geschichte dem tausendjahrigen Reich der Apokalypse entspricht, deren Text "vidi sedes ot sedentes super eas, et iudicium datum est" $/ 20,4 /$ auf die "praepositi per quos ecclesia nunc gubernatur / Mt 18, 18/" gedeutet wird /De civ. Dei XXII 9/".

5 Por. W. Simonis, Ecclesia visibilis et invisibilis. Untersuchungen zur Lkklesiologie und Sakramentenlehre in der afrikanischen Tradition von Cyprian bis Augustinus, Frankfurt a.M. 1970, 78: "Der Mangel an Toleranz, die auch den schlcchten Christen gegendber geboten ist, ist fur Augustinus lediglich ein Zeichen der fehlenden Demut und des Ilochmutes, der lieber in einem eigenen, selbstgegrundeten Konventikel sitzen will, anstatt ill Hause des Herrn zu dienen. Der Hochmut sucht das Ligene, die Demut sucht das Wonl der Kirche in Dienste Christi".

6 Por. In Joannis Evangelium 13, 17, PL 35, 1501; Simonis. dz.cyt., 79 .

7 Por. Sermo 340, PL 39, 1705-1706; Enchiridion ad Laurentium 72, 
śc ${ }^{8}$ : tym sprawom poświęcał Augustyn w swoich homiliach 1 pismach niezwykle dużo miejsca.

3. Powyzsze uwagi dotyczące teologii Kośc1oła, a przede wszystkim jego diakonijnej struktury, wydaja sie konieczne, a to dlatego, że przekonanie o tym wymiarze Kościoła, zrozumienie siebie jako służebnego właśnie, decydują o istnieniu diakonów. I odwrotnie: brak diakonów whierarchicznej strukturze Kościoła, znamionuje jego upadek, instytucjonalizacje, klerykalizacje, pozbawienie wymiaru charyzmatycznego ${ }^{9}$.

4. Sw. Augustyn wskazuje na istnienio dwu stanow wościele: duchownego 1 świecklego. Duchowni to "ordinati in ecclesiastici ministeril gradibus" ${ }^{10}$, a świeccy to plebs lub populus ${ }^{11}$. Podział ten występuje wszędzio tam, gdzie Augustyn posługuje się obrazami, by przybliżyć rozumienie tajemnicy Kościoła: clało Chrystusa składa sie z wielu członków, a kaźdy ma określone zadanie. Dlatego istnieja różne stany w Kościele-dziewic, żonatych, wdowców, mnichów, duchownych i świeckich ${ }^{12}$.

Prawnymi następcami apostołów są biskupi, po nich nastepują prezbiterzy, następnie diakoni, a po nich inni duchowni ${ }^{13}$.

PL 40, 266, POK 10, 163-164; Epistola 130, 24, PL 33, 503504; Enarrationes in psalmum 49, 14, PL 36, 574-575; Epistola 122, 2, PL 33, 471-472; Sermo 47, 30, PL 38, 315-316; $207,1, \mathrm{PL} 38,1042-1043 ; 58,9-10, \mathrm{PL} 38,397-398$; 239, 4-6, PL $38,1128-1129$.

8 Sermo 111, 2, PL 38, 642-64.3.

9 Por. M. Meslin, Instytucje kościelne i klerykalizacja w Kościele starożytnya/w. II-V/, w: Socjologia religii. Wybór tekstów, wyboru dokonaz i opiac. F. Adauski., Kraków 1984, 96. Niezwykle waźne wydaja się tu równieź stwierdzenia E. Schillebeeckx'a dotyczące tegro okresu: Christliche Identitut und kirchliches Ant, Dusseldorf 1985, 160-161, 176-179.

10 Lnarrationes in psaliaum $67,19, \mathrm{PL} 36,824$.

11 Por. Serno 91, 5, PL 38, 569; In Joannis Evangelium 41, 10. PL 35, 1697 .

12 Por. Serwo 96, 7, 9, PL 38, 588; Th. Specht, Die Lehre von der Kirche nach dem hl. Augustin, Jaderborn 1892, 106.

13 Por. Epistola $43,3,7, \mathrm{PL} 33,163$ : "/.../ presbiteri, diaconi aut inferioris ordinis clerici"; B. Altaner-B. Stuiber, Patrologie, Freiburg 19807, 443-445; W. Lborowicz, Augustyn, EK I 1103-1106; tenic, Augustyn, SirP 72-75. 
Ks. Jan Czuj uważa, że Loktor Lask1 "odziedziczył po wiekach poprzednich tak jasna 1 skrystalizowana naukę o hierarchii kośc1elnej, że niewiele mógł od siebie dodać, a chyba tu 1 ówdzie naukę tę pogłębić"14. Nie da się tez na podstawie pism Biskupa Hippony przedstawić relacji zachodzących pomiędzy episkopatein, prezilteratem 1 diakonatem a sakramentem święceń ${ }^{15}$.

5. W pismach swoich św. Augustyn wielokrotnie wspomina diakonów. Na prośbę diài ona Deogratiasa z Kartaginy napisaz nawet jedno $z$ najstarszych dzieł katechetycznych: "De catechizandis rudibus", a traktat "De haeresibus" zawiera w tytule inie diakona Quodvultdeusa, który okazał się jego inspiratorem.

Swięci diakoni Szczepan 1 Tivrzyniec objaśniani sa w I1cznych poświ ęconych im kazaniach ${ }^{16} i$ stawiani jako przykłady wiernych naśladowców Chrystusa:

"Pierwsi idaz apostołowie, następnie diakoni.

A jednak pierwszy męczennik jest spośród diakonów, a nie spośród apostołów /.../. Szczepan - poniżony, Chrystus - wywyższony; jeden do ziemi przytłoczony, Chrystus na drzerie zawieszony /.../. Chrystus z katedry krzyża uczył Szczepana prawideł miłości. o dobry Nauczycielu, pięknieś wypowiedziaz

14 Hierarchia kościelna u św. Augustyna, Lublin 1925, 66. Już z koŕcem I w. Mała Azja staje sį̨ centrum młodego Kościoła. Stąd pochodzą rozmaite teksty o urzędzie wościele. Dlatego nie bez racji zauważa J. Danielou: "Tak więc afrykańskie chrześcijaństro jeszcze przed Tertulianem przedstawia się nan jako pokaźne liczebnie, lecz nie przejawiające żadnej oryginalności. Podobnie wszystkie prądy, z jatemi snotykany się w Afryce w jego czasach, wywodzą się głównie z Azji, skizd częstokroć przenikały za pośrednictwem Rzynu" /J. Daniélou-II. I. Marrou, IIistoria Kościoła, tłum. M. Tarnowska, t. 1, 128. Zob. takize 191-248; J. Czuj, Kościół u św. Augustyna, PT 4/1923/209-227, 281-298/. Nie należy zạominać, że Augustyn znał rozróżnienie pomiędzy biskupem a prezbitereiil, $j$ ak $i$ miçay prezbiteren a diakonem. Pisał bowien do siw. ilieronima prezbitera: "/.../ rogo, ut me fidenter corrigas, ubi mihi hoc opus esse perspexeris. Quanquam enia secundum homorum vocabula, quae iam ecclesiae usus obtinuit, episcopatus presbyterio mator sit, tamen in multis rebus Augustinus IIieronylu minor est". / Lipistola 82, 4, 33, PL 33, 290/; Specht, dz.cyt., 122 .

15 Spccht podejmujł̨c tę kivestį /jw. s. 122/, zwraca uwagę, że jego młodszy rodak optat $z$ Mlllewe traktuje je jako trzy różne stopnie jednego 1 tego samego sacerdotiun / De schismate donatistarum I $13 /$.

16 Por. Sermones 302-305, PL 38, 3385-1400/sw. Wawrzyniec/: 
1 pięknieś nauczył. Oto uczeń Twój modli się za wrogów swoich, modli się za kamienujących go. Pokazał, w jaki sposób powinien naśladowác pokorny - Wzniosłego, stworzenie - Stwórce, ofiara Pośrednika, człowi ek - Boga-Człowieka"17!

W ich ślad w czasach spokoju winni wstępować chrześcijanie jako diakoni na wzór posłusznego aż do śmierci Chrystusa - pierwszego diak ona.

Jak wcześniej w Tagaście 1 jako prezbiter ze swymi przyjaciółmi, tak i jako biskup ze swoim klerem kontynuował klasztorne życie wspólne. Pośród nich znajdowali siq takíe diakoni, a mianowicie: diakon tialens, Faustus, Sewer, Herakliusz i nie wymieniony $z$ inienia diakon $z$ Hippony ${ }^{18}$.

6. Diakoni zajmuja miejsce tuz po prezbiterach. Ich ustanowienie łączy się z działalnościa apostołów w pierwotnej gminie Jerozolinskiej ${ }^{19}$, a ich obowiazki odpowiadaja tradycyjnemu już podziałowi przejawiającemu się w posłudze słowa, sakramentu 1 funkcjach charytatywnych ${ }^{20}$. Spełniane one były pou okiem biskupa lub prezbitera. Obowiczzki te zdaniem Augustyna sa tak poważne i ciężkie, że nie waha się ich porównać z obowiązkami prezbitera, a nawet biskupa 21 .

Tak Kościół, jak sprawujįcy w nim na mocy święceń urząd, w przekonaniu św. Auglistyna - to wspólnota diakonijna. Stojacy na joj czele spełniają posługe, a nie władzę. Już od Tertuliana można zauważyć tendencję do stopniowego wprowadzania starotestamentalnej nowenklatury na określenie biskupa, prezbitera $i$ Eucharystil. Wprawdzie św. Cyprian jako pierwszy używa terminu "sacerdos" na określenie biskupa, stwierdzajac, że to on właśnie działa "vice Christi"22, to jednak Augustyn daleki jest od

Sermones 314-323, PL 38, 1245-1446/św. Szczepan/. Sermo 197, 1, 8, tłum. J. Jaworski, PSP 12, 61, 65-66.

18 Tniona te znamy $z$ mowy 356 , PL $39,1574-1581$, PSP 12, 282292 .

19 Por. Serno 316, 1, PL 38, 1431-1432; 317, 1, PL 38, 1435.

20 Por. Sernones: 139, 302, 304, oraz Epistola 55, 18, 34 .

21 Por. Epistola 21, 1, PL 33, 88.

22 Por. Epistola 63, 14, PL 4, 386: "sacerdos vice Christi vere fungitur". 
nazywania biskupów 1 prezbiterów kapłanami w sonsie pośredników mięuzy Chrystusem a zgromadzoną wspólnotą ${ }^{23}$.

To wszystko sprawia, że diakoni, będący znakiem Kościoła służebnego, są obecni, sprawują swą posługe słowa, sakramentu 1 czynnej miłości. Niektórzy z nich razem ze swym biskupem wiodą życie wspólne, wzorowane na życiu wspólnoty Jerozolimskiej. Diakoni-męczennicy, jak św. Szczepan 1 Wawrzyniec, okazuja sie wzorami dla słuchającej sivego biskupa wspólnoty Kościoła.

Marek Marczewski - Lublin

\section{DIE DIAKONE BEI IIL. AUGUSTINUS /Zus ammenfassung/}

Sowohl die Kirche als auch diejenigen, die Kraft der Weihen das Amt in ihr ausuben, bilden in der Uberzeugung des hl. Augustinus eine diakonische Gemeinschaft. Die an ihrer Spitze stehenden Personen Uben keine Wachi aus, sondern ein Dienstant. Schon seit Tertulian wird eine Tendenz zur allmallichen Einfuhrung der alttestamentlichen Nomenklatur zur Bezeichnung des Bischofs, des Presbyters und der Eucharistie bemerkbar.

Der hl. Cyprian benutzt zwar als erster den Begriff "sacerdos" zur Bezeichnung des Bischofs und sagt, dass dieser "vice Christi" wirkt: "Sacerdos vice Christi vere fungitur" /Ep. 63, 14, PL 4, 386/, aber Augustinus liegt es fern, die Bisch8fe und Presbyter als Priester in Sinne von Vermittlern zwischen Christus und der versammelten Geneinde zu bezeichnen/Contra epistolam Parmeniani II $8,15-16$, PL 43,59-60/. All das bewirkt, dass die ein Zeichen der dienenden Kirche bildenden Diak one anwesend sind und ihren Dienst des Wortes, des Sakranents und der tatigen Liebe erfullen. Linige von ihnen fuhren zus ammen mit ihrea Bischof ein gemeinsanes Leben nach dew Vorbild des Lebens in der Jerusalemer Urgeneinde. Die Mllertyrerdiakone, wie der hl. Stephanus und Laurentius erweisen sich als Vorbilder fur die aut ihnen Bischof horende Gemeinschaft der Kirche.

23 Por. Contra epistolan Parmeniani II 8, 15-16, PL 43, 59-60. 